\title{
Response of Cabbage Seedlings to Different Sources of Arbuscular Mycorrhiza
}

\author{
MAH Bhuiyan ${ }^{1 *}$, MB Banu ${ }^{2}$, F Alam ${ }^{3}$, ME Ali ${ }^{4}$ and MR Khatun ${ }^{5}$ \\ ${ }^{1}$ Principal Scientific Officer, Soil Microbiology Laboratory, Bangladesh Agricultural Research Institute, Gazipur-1701, Bangladesh; ${ }^{4}$ Senior Scientific Officer, \\ Soil Microbiology Laboratory, Bangladesh Agricultural Research Institute, Gazipur-1701, Bangladesh; 2,3\&5Scientific Officer, Soil Microbiology Laboratory, \\ Bangladesh Agricultural Research Institute, Gazipur-1701, Bangladesh
}

\begin{abstract}
The effect of different sources of Arbuscular mycorrhiza (AM) fungi on cabbage seedlings (Atlas-70) were conducted. Eight sources of AM fungi viz. Jessore (AM-01), Rahmatpur (AM-02), Joydebpur (AM-03), Ullapara (AM-04), Jamalpur (AM-05), Hathazari (AM-06), Ishurdi (AM-07), Rajshahi (AM-08) from different AEZs of Bangladesh were studied along with a control and mixed sources on cabbage seedlings. Soil based AM inoculum at the rate of $2.0 \mathrm{~kg} \mathrm{~m}^{-2}$ was used. Biomass yield of cabbage (Atlas-70) increased from $28.0 \%$ to $130.7 \%$ in $2007-08$ and $44.8 \%$ to 96.9\% in 2008-09 over control by inoculation with different sources of AM. The highest biomass yield (503 mg seedling $^{-1}$ in 2007-08 and 321 mg seedling $^{-1}$ in 2008-09) of cabbage was observed with Jamalpur source which was identical to all AM source except Ishurdi source in 2007-08 and with Joydebpur source which was identical to all Jamalpur source in 2008-09. Uptake of all the nutrients by cabbage seedlings was also improved by inoculation with AM fungi. The AM fungi from all the sources appeared to be effective in enhancing the growth and development of cabbage seedlings.
\end{abstract}

Key words: Cabbage, Arbuscular mycorrhiza source, seedling

\section{Introduction}

Arbuscular mycorrhizal fungi are beneficial fungi which form symbiotic association with roots of the most plant species and help them in uptake of nutrients and moisture from the soil ${ }^{1}$. A part of fungal mycelia enters inside the cortical region of plant roots and the other part remains outside the root surface and extends in the rhizosphere soil. The external mycelium functions as the extension of the root hairs. They absorb nutrients and moisture from the rhizosphere soil and transfer them into the host plant through arbuscules in the cortical cells. The external AM hyphae extend several centimeters from the infected root surface and help in exploration of greater soil volume to absorb more nutrients and moisture from the soil. They increase the rate of photosynthesis and production of growth regulating substances of the host plants ${ }^{2-3}$. They improve $\mathrm{P}$ uptake from less soluble sources like phosphate rocks and also from the fixed forms like Fe- and Al-phosphates ${ }^{4}$. The AM fungi also help plants in resisting soil born root diseases ${ }^{5-6}$. Thus the fungi might be helpful in controlling damping off disease of vegetable seedlings in the nursery. The effectiveness of AM fungi varies with the ecology of their habitat.

Planting healthy and vigorous seedlings of vegetable, spices and fruit crops is the pre-requisite for harvesting good crops. AM fungi might be helpful in producing healthy and vigorous seedlings of vegetable, spices and fruit crops. The mycorrhizal seedlings are expected to perform better in the field because the AM fungi could be carried over to the field with infected roots. In view of this information the present investigation was undertaken i) to observe the effect of different sources of AM fungi on the performance of cabbage seedlings, ii) to identify better source(s) of AM for producing cabbage seedlings and iii) to uptake nutrients by cabbage seedlings.

\section{Materials and Methods}

The effect of different sources of AM fungi were conducted on cabbage seedlings in the seedbed ( $3 \mathrm{~m} \times 1 \mathrm{~m}$ ) of Soil Science Division, BARI, Gazipur during rabi seasons of 2007-08 and 2008-09. The silted (sandy clay loam) soils from the bank of Turag river at Kodda, Gazipur was used in the seedbed.

The experiment was laid out in randomized complete block (RCB) design with four replications. Eight different sources of AM fungi viz. Jessore (AM-01), Rahmatpur (AM-02), Joydebpur (AM-03), Ullapara (AM-04), Jamalpur (AM-05), Hathazari (AM-06), Ishurdi (AM-07), Rajshahi (AM-08) from different AEZs of Bangladesh were studied along with a Control and mixed sources of AM on cabbage seedlings. The seed bed was divided into 10 separate unit plot by inserting thick polyethylene sheet up to $25 \mathrm{~cm}$ depth of soil to check the contamination of AM source among the plots. Cowdung were used at the rate of $5 \mathrm{~kg} \mathrm{~m}^{-2}$. No other fertilizers were used.

* Corresponding author:

Dr. MAH Bhuiyan, Principal Scientific Officer, Soil Microbiology Laboratory, Bangladesh Agricultural Research Institute, Gazipur-1701, Bangladesh, Tel. (Office): (02) 9252893, Cell. 01720051657,E-mail: mahbhuiyan63@yahoo.com 
Seeds of cabbage were sown in $10 \mathrm{~cm}$ apart solid lines on 13 November 2007 and 11 November 2008.

Soil based AM inoculum @ $2 \mathrm{~kg} \mathrm{~m}^{-2}$ was used in the seed furrows of about $3 \mathrm{~cm}$ depth. A soil layer of about $1 \mathrm{~cm}$ thickness was spread on the inoculum layer on which the seeds were sown. Seeds were sown in the soil layer above the inoculum to ensure penetration of the roots through the inoculum layer immediately after germination. Atlas-70 variety of cabbage was used. The seedlings were thinned down to about $3 \mathrm{~cm}$ from seedling to seedling within a week of germination. Watering, weeding and other intercultural operation were done whenever necessary. The seedlings of cabbage were harvested on 11 December 2007 and 17 December 2008. Biomass yield and yield components of the seedlings were recorded on the day of harvesting. The seedlings were cut down at the soil layer and root length, seedling height, root weight and shoot weight (oven dry) were taken separately. Seedling height was measured from the soil layer to the tip of the stem. Root length was measured from the soil layer to the tip of the root. Collar diameter was measured with a slide calipers $2 \mathrm{~cm}$ above the soil layer.

The seedlings were harvested carefully by uprooting. Roots of the seedlings were washed to remove the adhered soils and were then excised for AM colonization studies. The seedlings were oven dried to a constant weight at a temperature of $70^{\circ} \mathrm{C}$ and the dry weight of shoot and root was recorded separately. Chemical analyses of the whole seedlings (shoot plus root) were done and nutrient uptakes by the seedlings were calculated.

Hundred grams soil sample plot ${ }^{-1}$ was used to count the spore numbers during collection of seedlings. The spore numbers were determined by Wet Sieving and Decanting Method ${ }^{7}$. To assess AM root colonization, the roots were processed according to Koske and Gemma (1989) and observed under a compound microscope ${ }^{8}$. Presence of fungal bodies (mycelium, spores, arbuscules and vesicles) in the root tissues were considered as positive for infection. Percent of root colonization was calculated as follows:

Root colonization $=\frac{\mathrm{N}+\mathrm{ve}}{\mathrm{N}} \times 100(\%)$

Where, $\mathrm{N}+$ ve $=$ Number of AM positive segments

$\mathrm{N}=$ Total number of segments observed

Data were analyzed using the statistical package IRRISTAT and MSTAT-C.

\section{Results and Discussion}

Physical and chemical properties of soil

Physical and chemical properties of the soil are presented in Table 1 . The soil was slightly alkaline in reaction. The organic matter, major nutrients and zinc and copper contents of the soil were low, while iron, copper and manganese levels were quite high. The soil contained $10 \mathrm{AM}$ spores of indigenous mixed AM fungal species and the experiment was conducted under non-sterilized soil condition.

\section{Biomass and yield components}

Biomass yield and yield components like seedling height, number of leaves seedling ${ }^{-1}$, collar diameter and shoot and root weight in 2007-08, and seedling height, root length and shoot weight of cabbage seedlings in 2008-09 were significantly influenced by AM inoculation (Figs. 1-2 and Table 2). Root length in 2007-08 and collar diameter, number of leaves plant ${ }^{-1}$ and root weight in 2008-09 was non-significant. Biomass yield increased from 28.0 to 130.7 percent in 2007-08 and 44.8 to 96.9 percent in 2008-09 with different sources of AM. The highest biomass yield (503 mg seedling ${ }^{-1}$ ) was observed with Jamalpur source which was closely followed by that with

Table 1. Physical and chemical properties of the soil used in seedbed

\begin{tabular}{lcc}
\hline $\begin{array}{l}\text { Soil variable } \\
\text { Texture }\end{array}$ & $\begin{array}{c}\text { Content } \\
\text { Sandy clay loam }\end{array}$ & Critical level \\
\hline $\mathrm{pH}$ & 7.4 & \\
Organic matter (\%) & 0.53 & \\
Total $\mathrm{N}(\%)$ & 0.03 & 14 \\
Available P $\left(\mu \mathrm{g} \mathrm{g}^{-1}\right)$ & 11.0 & 14 \\
Available S $\left(\mu \mathrm{g} \mathrm{g}^{-1}\right)$ & 10.0 & 0.2 \\
Exchangeable $\mathrm{K}\left(\right.$ meq $\left.100 \mathrm{~g}^{-1}\right)$ & 0.15 & 2.0 \\
Exchangeable Ca (meq $\left.100 \mathrm{~g}^{-1}\right)$ & 3.80 & 0.8 \\
Exchangeable $\mathrm{Mg}^{-1}$ meq $\left.100 \mathrm{~g}^{-1}\right)$ & 1.10 & 2.0 \\
Available $\mathrm{Zn}\left(\mu \mathrm{g} \mathrm{g}^{-1}\right)$ & 2.50 & 1.0 \\
Available $\mathrm{Cu}\left(\mu \mathrm{g} \mathrm{g}^{-1}\right)$ & 2.10 & 10 \\
Available Fe $\left(\mu \mathrm{g} \mathrm{g}^{-1}\right)$ & 35 & 5.0 \\
Available $\mathrm{Mn}\left(\mu \mathrm{g}^{-1}\right)$ & 11 & \\
\hline
\end{tabular}




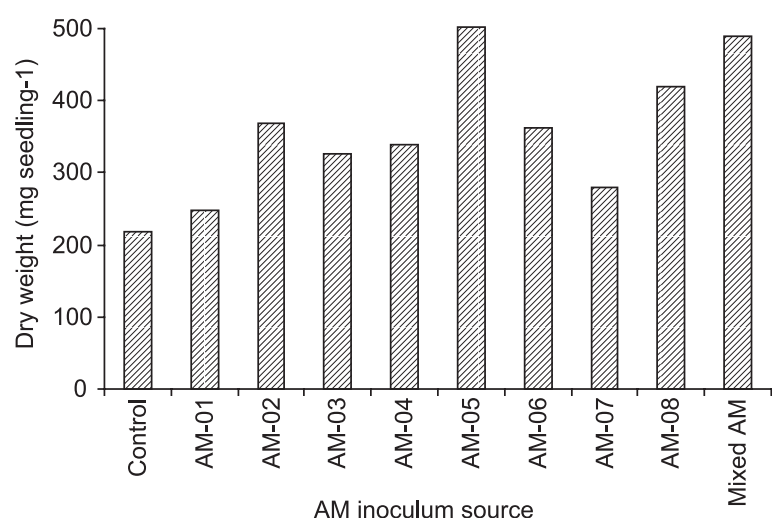

Figure 1. Effect of AM inoculum source on dry weight of cabbage seedlings during 2007-08.

Rajshahi source and mixed AM (420 and 489 mg seedling ${ }^{-1}$, respectively) in 2007-08. Biomass yield with the remaining sources in 2007-08 varied from 247 to 368 mg seedling $^{-1}$ and the uninoculated control treatment produced the lowest biomass

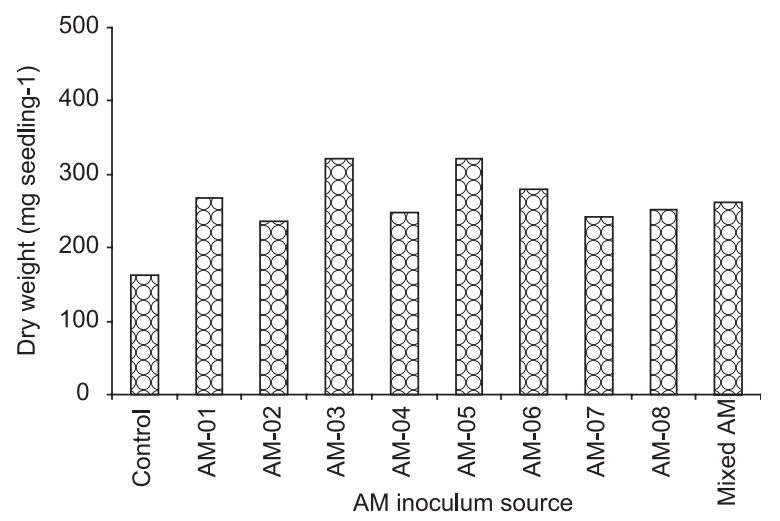

Figure 2. Effect of AM inoculum source on dry weight of cabbage seedlings during 2008-09.

(218 mg seedling ${ }^{-1}$ ). The highest biomass yield (321 mg seedling $^{-1}$ ) in 2008-09 was observed with Joydebpur source and Jamalpur source which was closely followed by that with Hathazari source (279 mg seedling ${ }^{-1}$ ). Biomass yield in 2008-

Table 2. Effect of arbuscular mycorrhiza (AM) inoculum on biomass yield and yield components of cabbage seedlings (Atlas 70) during rabi season 2007-08 and 2008-09

\begin{tabular}{|c|c|c|c|c|c|c|}
\hline AM Inoculum source & $\begin{array}{c}\text { Seedling } \\
\text { height }(\mathrm{cm})\end{array}$ & $\begin{array}{c}\text { Root } \\
\text { length }(\mathrm{cm})\end{array}$ & $\begin{array}{c}\text { Collar } \\
\text { diameter (mm) }\end{array}$ & $\begin{array}{c}\text { No. of leaves } \\
\text { seedling }{ }^{-1}\end{array}$ & $\begin{array}{c}\text { Shoot } \\
\text { weight } \\
\left(\mathrm{mg} \mathrm{plant}^{-1}\right) \\
\end{array}$ & $\begin{array}{c}\text { Root } \\
\text { weight } \\
\left(\text { mg plant }^{-1}\right) \\
\end{array}$ \\
\hline \multicolumn{7}{|l|}{ 2007-08 } \\
\hline Control & $10.9 \mathrm{~b}$ & 3.4 & $19.7 f$ & $2.80 \mathrm{c}$ & $197 \mathrm{e}$ & $21 c$ \\
\hline Jessore (AM-01) & $17.7 \mathrm{a}$ & 4.8 & $2.10 \mathrm{ef}$ & $6.10 \mathrm{ab}$ & 207de & $40 a b c$ \\
\hline Rahmatpur (AM-02) & $18.0 \mathrm{a}$ & 5.0 & $2.08 \mathrm{ef}$ & $5.70 \mathrm{ab}$ & 328bc & $40 \mathrm{abc}$ \\
\hline Joydebpur (AM-03) & 19.3a & 5.5 & $2.77 c d$ & $5.50 \mathrm{~b}$ & 294b-e & 33bc \\
\hline Ullapara (AM-04) & $19.5 \mathrm{a}$ & 5.9 & 2.56de & $6.00 \mathrm{ab}$ & 304bcd & $36 \mathrm{bc}$ \\
\hline Jamalpur (AM-05) & $20.0 \mathrm{a}$ & 5.2 & $3.02 \mathrm{bcd}$ & $5.80 \mathrm{ab}$ & $455 a$ & $48 a b$ \\
\hline Hathazari (AM-06) & $21.6 a$ & 6.1 & 3.14bc & 6.10ab & 330bc & $32 \mathrm{bc}$ \\
\hline Ishurdi (AM-07) & $17.2 \mathrm{a}$ & 4.2 & $2.07 \mathrm{ef}$ & $5.50 \mathrm{~b}$ & 247cde & $32 \mathrm{bc}$ \\
\hline Rajshahi (AM-08) & $20.3 a$ & 5.5 & $3.78 \mathrm{a}$ & $6.40 \mathrm{a}$ & 390ab & $30 \mathrm{bc}$ \\
\hline Mixed AM & $21.2 \mathrm{a}$ & 6.9 & 3.53ab & $6.00 \mathrm{ab}$ & $431 \mathrm{a}$ & $58 a$ \\
\hline F test & $* *$ & NS & $* *$ & $* *$ & $* *$ & $*$ \\
\hline CV(\%) & 9.5 & 15.2 & 8.1 & 6.1 & 12.9 & 21.4 \\
\hline \multicolumn{7}{|l|}{ 2008-09 } \\
\hline Control & $14.8 \mathrm{c}$ & $5.0 \mathrm{c}$ & 1.98 & 4.30 & $143 c$ & 20 \\
\hline Jessore (AM-01) & $20.2 b$ & 6.3abc & 2.27 & 5.20 & $239 b$ & 29 \\
\hline Rahmatpur (AM-02) & $20.5 b$ & $5.4 \mathrm{bc}$ & 2.43 & 5.00 & $212 b$ & 24 \\
\hline Joydebpur (AM-03) & $23.7 \mathrm{a}$ & 6.6ab & 2.62 & 5.65 & $288 \mathrm{a}$ & 33 \\
\hline Ullapara (AM-04) & 22.3ab & $5.4 \mathrm{bc}$ & 2.36 & 4.60 & $220 b$ & 28 \\
\hline Jamalpur (AM-05) & $22.4 \mathrm{ab}$ & $5.9 \mathrm{bc}$ & 2.44 & 4.85 & 293a & 28 \\
\hline Hathazari (AM-06) & $23.6 \mathrm{a}$ & 6.8ab & 2.74 & 5.05 & $247 b$ & 32 \\
\hline Ishurdi (AM-07) & $20.4 b$ & $7.8 \mathrm{a}$ & 2.30 & 4.85 & $213 b$ & 29 \\
\hline Rajshahi (AM-08) & $20.5 b$ & $5.7 \mathrm{bc}$ & 2.26 & 4.90 & $227 b$ & 24 \\
\hline Mixed AM & $20.5 b$ & $6.8 \mathrm{ab}$ & 2.50 & 5.20 & $238 b$ & 23 \\
\hline F test & $* *$ & $* *$ & NS & NS & $* *$ & NS \\
\hline CV(\%) & 8.0 & 14.9 & 15.2 & 10.8 & 11.4 & 24.5 \\
\hline
\end{tabular}

In a column, the figure(s) having same letter are not significantly different at 5\% level of probability by DMRT 
09 with the remaining sources varied from 236 to $268 \mathrm{mg}$ seedling $^{-1}$ and the uninoculated control treatment produced the lowest biomass (163 mg seedling ${ }^{-1}$ ). In 2007-08, height of cabbage seedlings with different sources of AM inoculum ranged from 17.2 to $21.6 \mathrm{~cm}$; while the height with control treatment was $10.9 \mathrm{~cm}$ but in 2008-09, height of cabbage seedlings with different sources of AM inoculum ranged from 20.2 to $23.7 \mathrm{~cm}$; while the height with control treatment was $14.8 \mathrm{~cm}$.

Better performance of inoculated seedlings might be due to beneficial effects of AM fungi. There are many evidences of better performance of AM inoculated seedlings compared to those without inoculation ${ }^{9-11}$. Khanam (2002) also found wide variation in AM fungi species composition among different agro-ecological situation. Such variation in AM fungi species composition might have been influenced the performance of cabbage seedlings differently ${ }^{12}$.

Effect of AM inoculum on root colonization and spore number

Effect of different sources of AM inoculum on root colonization by AM fungi and spore numbers in rhizosphere soils of cabbage seedlings are presented in Table 3. In 200708 , root colonization by AM fungi from different sources was found identical, which was better than control seedlings. But in 2008-09, root colonization by AM fungi from different sources was not identical. In both the seasons, the highest root colonization was observed in Jamalpur source. There was also some root colonization in the control seedlings with native AM fungi. This might be due to survival of some native AM fungi in soil. The highest number of spores in the rhizospere soils was observed with the AM inoculum source from Jamalpur, which was identical to those with the sources of Joydebpur, Ullapara and Rajshahi in 2007-2008 but superior to those with other sources and control, and with the sources of Hathazari and mixed AM source in 2008-2009 but superior to other sources. Rhizosphere soils from control seedlings also contained some AM spores because of some root colonization with native AM fungi. Sattar and Khanam (2006) found higher root colonization in different sources of AM compared to non AM inoculated control seedlings of chilli ${ }^{11}$. Satter et al. (2004) also found significantly higher root colonization by AM fungi and spore number in rhizosphere soils of different sources compared to non AM inoculated brinjal seedlings ${ }^{13}$.

In the AM inoculated cabbage seedlings, root colonization varied from 35 to 50 percent and spore numbers in rhizosphere soil ranged from 20 to $50100 \mathrm{~g}^{-1}$ soil in 2007-08 and root colonization varied from 45 to 70 percent and spore numbers in rhizosphere soil ranged from 30 to $70100 \mathrm{~g}^{-1}$ soil in 200809 (Table 3). The control seedlings also had some root colonization (10\% in 2007-08 and 25\% in 2008-09), and spore population (10 nos. in 2007-08 and 15 nos. in 2008-09 $100 \mathrm{~g}^{-}$ ${ }^{1}$ soil) in the rhizosphere soils with the native AM fungi.

Effect of AM inoculum on nutrient uptake

Nutrient uptake by cabbage seedlings has been presented in Tables 4 and 5. Uptake of all the major nutrients by cabbage

Table 3. Effect of arbuscular mycorrhiza (AM) inoculum on root colonization by AM fungi and spore number in rhizosphere soils of cabbage seedlings (Atlas 70) during rabi season 2007-08 and 2008-09

\begin{tabular}{lccccc}
\hline AM Inoculum source & \multicolumn{2}{c}{ Root colonization $(\%)$} & & \multicolumn{2}{c}{ Spore no. $\left(100 \mathrm{~g}^{-1}\right.$ soil $)$} \\
\cline { 2 - 3 } \cline { 5 - 6 } Control & $2007-2008$ & $2008-2009$ & & $2007-2008$ & $2008-2009$ \\
Jessore (AM-01) & $10.0 \mathrm{~b}$ & $25.0 \mathrm{e}$ & & $10.0 \mathrm{e}$ & $15.0 \mathrm{e}$ \\
Rahmatpur (AM-02) & $45.0 \mathrm{a}$ & $45.0 \mathrm{~d}$ & & $20.0 \mathrm{~d}$ & $30.0 \mathrm{~d}$ \\
Joydebpur (AM-03) & $35.0 \mathrm{a}$ & $50.0 \mathrm{~cd}$ & & $35.0 \mathrm{c}$ & $45.0 \mathrm{c}$ \\
Ullapara (AM-04) & $40.0 \mathrm{a}$ & $60.0 \mathrm{abc}$ & & $45.0 \mathrm{ab}$ & $55.0 \mathrm{bc}$ \\
Jamalpur (AM-05) & $40.0 \mathrm{a}$ & $55.0 \mathrm{bcd}$ & & $50.0 \mathrm{a}$ & $55.0 \mathrm{bc}$ \\
Hathazari (AM-06) & $50.0 \mathrm{a}$ & $70.0 \mathrm{a}$ & & $50.0 \mathrm{a}$ & $70.0 \mathrm{a}$ \\
Ishurdi (AM-07) & $45.0 \mathrm{a}$ & $60.0 \mathrm{abc}$ & & $40.0 \mathrm{bc}$ & $65.0 \mathrm{ab}$ \\
Rajshahi (AM-08) & $40.0 \mathrm{a}$ & $55.0 \mathrm{bcd}$ & & $20.0 \mathrm{~d}$ & $50.0 \mathrm{c}$ \\
Mixed AM & $40.0 \mathrm{a}$ & $65.0 \mathrm{ab}$ & & $50.0 \mathrm{a}$ & $55.0 \mathrm{bc}$ \\
F test & $45.0 \mathrm{a}$ & $65.0 \mathrm{ab}$ & & $25.0 \mathrm{~d}$ & $65.0 \mathrm{ab}$ \\
CV(\%) & $* *$ & $* *$ & $* *$ & $* *$ \\
\hline
\end{tabular}

In a column, the figure(s) having same letter are not significantly different at $5 \%$ level of probability by DMRT 
seedlings was improved by inoculation with different sources of AM fungi. Like major nutrients, uptake of all the micronutrients by cabbage seedlings was also improved by inoculation with AM fungi. The external hyphae of AM fungi might have helped the seedlings to uptake more nutrients from the soil. Uptake of most of the nutrients by cabbage seedlings varied widely among different sources of AM fungi.

The external hyphae can extend up to several centimeters beyond the mycorrhizal root surface and can increase root surface area and the absorption zone for exploration of greater soil volume for nutrient and moisture uptake ${ }^{14}$. Mycorrhizal fungal hyphae were found to intercept labeled P placed $27 \mathrm{~cm}$ apart from a mycorrhizal root, whereas it remained unavailable to non-mycorrhizal roots ${ }^{15}$. The radius of the depletion zone for $\mathrm{P}$ around mycorrhizal onion roots was found twice that for non-mycorrhizal roots ${ }^{16}$. The rate of nutrient uptake by mycorrhizal roots is also faster than that by non-mycorrhizal roots $^{17}$.

Table 4. Effects AM inoculum on uptake of major nutrients by cabbage (Atlas 70) seedlings during rabi 2007-08 and 2008-09

\begin{tabular}{|c|c|c|c|c|c|c|}
\hline \multirow[t]{2}{*}{ AM Inoculum source } & \multicolumn{6}{|c|}{ Uptake of major nutrients (mg seedling ${ }^{-1}$ ) } \\
\hline & $\mathrm{N}$ & $\mathrm{P}$ & $\mathrm{K}$ & $\mathrm{Ca}$ & $\mathrm{Mg}$ & $\mathrm{S}$ \\
\hline \multicolumn{7}{|l|}{ 2007-08 } \\
\hline Control & $4.86 \mathrm{e}$ & 1.61 & 1.50 & $5.44 d$ & $5.44 d$ & $1.26 \mathrm{~d}$ \\
\hline Jessore (AM-01) & $8.75 \mathrm{~cd}$ & 2.71 & 2.12 & $9.57 b c$ & $9.74 \mathrm{bc}$ & 2.30cd \\
\hline Rahmatpur (AM-02) & $9.59 \mathrm{bcd}$ & 2.75 & 2.86 & $12.28 \mathrm{ab}$ & 12.15ab & $2.15 \mathrm{~cd}$ \\
\hline Joydebpur (AM-03) & $7.81 \mathrm{~d}$ & 2.71 & 2.41 & $10.36 b$ & $10.31 \mathrm{bc}$ & $2.14 \mathrm{~cd}$ \\
\hline Ullapara (AM-04) & $8.45 \mathrm{~cd}$ & 2.61 & 2.09 & $9.43 \mathrm{bc}$ & $9.57 b c$ & 2.95bc \\
\hline Jamalpur (AM-05) & $12.82 \mathrm{a}$ & 4.02 & 3.03 & $14.95 a$ & $14.95 a$ & $5.19 a$ \\
\hline Hathazari (AM-06) & 10.66abc & 3.21 & 2.34 & $9.38 \mathrm{bc}$ & $9.38 b c$ & 4.15ab \\
\hline Ishurdi (AM-07) & 9.77bcd & 2.12 & 1.54 & $6.70 \mathrm{~cd}$ & 6.70cd & $3.04 \mathrm{bc}$ \\
\hline Rajshahi (AM-08) & $9.83 \mathrm{bcd}$ & 3.37 & 2.72 & $10.40 \mathrm{~b}$ & $10.51 \mathrm{bc}$ & 4.31ab \\
\hline Mixed AM & 11.68ab & 3.83 & 3.12 & $12.01 \mathrm{ab}$ & 12.18ab & $3.38 \mathrm{bc}$ \\
\hline F test & $* *$ & - & - & $* *$ & $* *$ & $* *$ \\
\hline CV(\%) & 11.9 & 24.4 & 23.8 & 13.8 & 15.8 & 20.6 \\
\hline \multicolumn{7}{|l|}{ 2008-09 } \\
\hline Control & $4.95 c$ & $1.07 \mathrm{e}$ & $5.14 d$ & $2.17 \mathrm{f}$ & $1.85 \mathrm{~d}$ & $1.81 \mathrm{f}$ \\
\hline Jessore (AM-01) & $8.24 b$ & $1.77 \mathrm{bcd}$ & $8.61 \mathrm{c}$ & $4.25 \mathrm{~cd}$ & $2.89 b c$ & 2.75de \\
\hline Rahmatpur (AM-02) & $7.27 \mathrm{~b}$ & $1.60 \mathrm{~d}$ & $8.91 b c$ & $3.47 \mathrm{e}$ & $2.91 b c$ & $2.29 \mathrm{e}$ \\
\hline Joydebpur (AM-03) & $9.76 a$ & $2.36 \mathrm{a}$ & $11.21 \mathrm{a}$ & $4.31 \mathrm{~cd}$ & $3.24 a b$ & 3.63ab \\
\hline Ullapara (AM-04) & $7.59 b$ & $1.79 \mathrm{bcd}$ & $8.25 c$ & 3.78de & 3.19ab & 3.09cd \\
\hline Jamalpur (AM-05) & $10.08 \mathrm{a}$ & $2.62 \mathrm{a}$ & $11.45 a$ & $5.47 \mathrm{a}$ & $3.56 a$ & $4.00 \mathrm{a}$ \\
\hline Hathazari (AM-06) & $8.48 \mathrm{~b}$ & $2.34 \mathrm{a}$ & 10.43ab & $5.02 \mathrm{ab}$ & $3.68 a$ & $3.32 b c$ \\
\hline Ishurdi (AM-07) & $7.46 \mathrm{~b}$ & $1.69 \mathrm{~cd}$ & $8.21 \mathrm{c}$ & 4.14cde & $2.37 c$ & 2.76de \\
\hline Rajshahi (AM-08) & $7.97 \mathrm{~b}$ & $2.00 \mathrm{bc}$ & $9.47 \mathrm{bc}$ & $4.62 \mathrm{bc}$ & $2.89 b c$ & 2.69de \\
\hline Mixed AM & $7.94 b$ & $2.03 \mathrm{~b}$ & $9.11 b c$ & 3.84de & $2.61 \mathrm{c}$ & 2.76de \\
\hline F test & $* *$ & $* *$ & $* *$ & $* *$ & $* *$ & $* *$ \\
\hline CV(\%) & 10.3 & 10.4 & 11.4 & 10.6 & 11.5 & 10.5 \\
\hline
\end{tabular}

In a column, the figure(s) having same letter are not significantly different at $5 \%$ level of probability by DMRT 
Table 5. Effects of of AM inoculum on uptake of micronutrients by cabbage (Atlas 70) seedlings during rabi 2007-08 and 2008-09

\begin{tabular}{|c|c|c|c|c|c|}
\hline \multirow[t]{2}{*}{ AM Inoculum source } & \multicolumn{5}{|c|}{ Uptake of micronutrients ( $\mu$ g seedling ${ }^{-1}$ ) } \\
\hline & B & $\mathrm{Cu}$ & $\mathrm{Fe}$ & Mn & $\mathrm{Zn}$ \\
\hline \multicolumn{6}{|l|}{ 2007-08 } \\
\hline Control & $93 e$ & 19.5 & 1029 & 172 & $92 \mathrm{c}$ \\
\hline Jessore (AM-01) & 174bc & 32.5 & 1979 & 298 & $158 b c$ \\
\hline Rahmatpur (AM-02) & $178 b$ & 40.4 & 1926 & 253 & $171 b c$ \\
\hline Joydebpur (AM-03) & 128b-e & 49.6 & 1840 & 297 & $171 b c$ \\
\hline Ullapara (AM-04) & $168 \mathrm{bc}$ & 39.3 & 1731 & 290 & $134 c$ \\
\hline Jamalpur (AM-05) & 164bcd & 49.2 & 2990 & 326 & $432 \mathrm{a}$ \\
\hline Hathazari (AM-06) & 120cde & 37.9 & 2156 & 313 & $140 \mathrm{bc}$ \\
\hline Ishurdi (AM-07) & 109de & 30.1 & 1551 & 237 & $84 c$ \\
\hline Rajshahi (AM-08) & 146b-e & 57.2 & 2342 & 343 & $157 b c$ \\
\hline Mixed AM & 239a & 47.6 & 2880 & 429 & $224 b$ \\
\hline F test & $* *$ & - & - & - & $* *$ \\
\hline CV(\%) & 15.0 & 22.3 & 23.4 & 23.2 & 19.7 \\
\hline \multicolumn{6}{|l|}{ 2008-09 } \\
\hline Control & $91 \mathrm{e}$ & $14.9 \mathrm{~d}$ & $706 \mathrm{~d}$ & $76 \mathrm{~d}$ & $78 \mathrm{f}$ \\
\hline Jessore (AM-01) & 186bcd & $24.1 \mathrm{bc}$ & 1359ab & $167 a$ & $211 \mathrm{a}$ \\
\hline Rahmatpur (AM-02) & 159d & $20.0 c$ & $1143 b c$ & $121 \mathrm{c}$ & 153cd \\
\hline Joydebpur (AM-03) & $226 a$ & $21.1 \mathrm{bc}$ & $1487 a$ & $164 a$ & $185 b$ \\
\hline Ullapara (AM-04) & $161 d$ & 22.3bc & 1195bc & $112 \mathrm{c}$ & $116 \mathrm{e}$ \\
\hline Jamalpur (AM-05) & 197bc & $25.6 a b$ & $1474 a$ & $165 a$ & $168 b c$ \\
\hline Hathazari (AM-06) & 199ab & $23.7 \mathrm{bc}$ & $1346 a b$ & $131 \mathrm{bc}$ & 171bc \\
\hline Ishurdi (AM-07) & 174bcd & $23.1 \mathrm{bc}$ & $1047 c$ & 150ab & $148 \mathrm{~cd}$ \\
\hline Rajshahi (AM-08) & 169bcd & $22.6 b c$ & 1273ab & $128 \mathrm{bc}$ & 137de \\
\hline Mixed AM & $167 c d$ & $28.6 \mathrm{a}$ & $1281 \mathrm{ab}$ & $123 c$ & 129de \\
\hline F test & $* *$ & $* *$ & $* *$ & $* *$ & $* *$ \\
\hline CV(\%) & 10.8 & 12.4 & 11.0 & 11.5 & 11.8 \\
\hline
\end{tabular}

In a column, the figure(s) having same letter are not significantly different at $5 \%$ level of probability by DMRT

\section{Conclusion}

From the result it is evident that AM fungi can improve nutrient uptake, and growth and development of cabbage seedlings. The AM fungi from all the sources appeared to be effective in enhancing the growth and development of cabbage seedlings. The fungi might be used to produce seedlings of this crop. Faster growth of seedlings might help to shorten the nursery life, and thereby would reduce the cost of seedling production. The AM inoculated seedlings might also perform better in the field because the AM fungi could be carried over to the field through the colonized roots. Field studies with AM inoculated seedlings might also be initiated.

\section{References}

1. Marschner H and Dell B. 1994. Nutrient uptake in mycorrhizal symbiosis. Plant Soil. 159: 89-102.

2. Syvertsen JP and Graham JH. 1999. Phosphorus supply and arbuscular mycorrhizas increase growth and net gas exchange response in two Citrus spp. grown at elevated $\mathrm{CO}_{2}$. Plant Soil. 208: 209-219.
3. Danneberg G, Latus C, Zimmer W, Hundes-Hagen B, Schneider-Poetsch H and Bothe H. 1992. Influence of vesicular-arbuscular mycorrhiza on phytohormone balances in maize (Zea mays L.). J. Plant Physiol. 141: 3339.

4. Bolan NS. 1991. A critical review on the role of mycorrhizal fungi in the uptake of phosphorus by plants. Plant Soil. 134: 189-207.

5. Bethelenfalvay GJ and Linderman RG. 1992. Mycorrhizae in Sustainable Agriculture. American Soc. Agron. Special Publication No. 54. Medison. USA.

6. Ho CT. 1998. Safe and efficient management systems for plantation pests and diseases. The Planter. 74: 369-385.

7. Gerdemann JW and Nicolson TH. 1963. Spores of mycorrhizal endogone extracted from soil by wet sieving and decanting. Trans. Brit. Mycol. Soc. 46: 235-244.

8. Koske RE and Gemma JN. 1989. A modified procedure for staining roots and detects VA mycorrhizas. Mycol. Res. 92: 486-505.

9. Masri BM. 1997. Mycorrhizal inoculation for growth enhancement and improvement of the water relations in mangosteen (Garcinia mangostana L) seedlings. PhD Thesis. Universiti Putra Malaysia, Serdang, Malaysia.

10. Satter MA. 2000. The arbuscular mycorrhiza and phosphate rock in rehabilitation of tin tailings with Acacia mangium and peanut agroforestry 
system. Ph.D Thesis. Faculty of Agric., Universiti Putra Malaysia, Serdang, Malaysia. pp. 1-255.

11. Satter MA and Khanam D. 2006. Effect of different sources of arbuscular mycorrhiza on the performance of chilli seedlings. Bangladesh J. Microbiol. 23(2): 98-101.

12. Khanam D. 2002. Biodiversity of arbuscular mycorrhizal fungi in agricultural crops and their interaction with Rhizobium on chickpea (Cicer arietinum L). Ph.D Thesis. Dept. of Soil Sci., Bangabandhu Sheikh Mujibur Rahman Agric. Univ., Gazipur, Bangladesh. pp. 1-226.

13. Satter, MA, Khanam D and Rahman MM. 2004. Effect of different sources of Arbuscular mycorrhiza on the performance of brinjal seedlings. The Agriculturists. 2(1): 104-110.
14. Johansen A, Jacobsen I and Jensen ES. 1993. External hyphae of vesiculararbuscular mycorrhizal fungi associated with Trifolium subterraneum L. 3. hyphal transport of ${ }^{32} \mathrm{P}$ and ${ }^{15} \mathrm{~N}$. New Phytol. 124: 61-68.

15. Hattingh MJ, Gray LE and Gerdemann JW. 1973. Uptake and translocation of ${ }^{32} \mathrm{P}$ labeled phosphate to onion roots by endomycorrhizal fungi. Soil Sci. 116: 383-387.

16. Owusu-Bennoah E and Wild A. 1980. Effects of vesicular-arbuscular mycorrhiza on the size of the labile pool of soil phosphate. Plant Soil. 54: 233-242.

17. Son CL and Smith SE. 1988. Mycorrhizal growth responses: interaction between photon irradiance and phosphorus nutrition. New Phytol. 108: 305-314. 